\title{
CLUSTERING REGIONAL BUSINESS CYCLES
}

Mn D. Gadea-Rivas, Ana Gomez loscos and Edrardo Bandres

Documentos de Trabajo. N. 1744

\section{BANCODE ESPAÑA}

\author{
Eurosistema
}


CLUSTERING REGIONAL BUSINESS CYCLES 
CLUSTERING REGIONAL BUSINESS CYCLES ${ }^{(*)}$

\author{
M. D. Gadea-Rivas ${ }^{(*)}$
}

UNIVERSITY OF ZARAGOZA

Ana Gómez-Loscos ${ }^{(* \star)}$

BANCO DE ESPAÑA

Eduardo Bandrés ${ }^{(* * *)}$

UNIVERSITY OF ZARAGOZA

$\left.{ }^{(*}\right)$ We are grateful to S. Kaufmann for sharing her codes with us. We also thank L. J. Álvarez, G. Hewings and J. F. Jimeno for their useful comments. M. D. Gadea acknowledges financial support from Funcas. The views expressed in this paper are the responsibility of the authors and do not represent those of the Banco de España or the Eurosystem.

$\left.{ }^{* \star}\right)$ Corresponding author: Department of Applied Economics, University of Zaragoza. Gran Vía, 4, 50005 Zaragoza (Spain). Tel.: +34 976 761842, fax: +34 976761840 and e-mail: Igadea@unizar.es.

$\left.{ }^{(\star \star \star}\right)$ Banco de España, Alcala, 48, 28014 Madrid (Spain). Tel.: +34 91 3385817, fax: +34 915310059 and e-mail: agomezloscos@bde.es.

$\left.{ }^{(\star \star \star \star}\right)$ Department of Applied Economics, University of Zaragoza. Gran Vía, 4, 50005 Zaragoza (Spain). Tel.: +34 976 761846, fax: +34 976761840 and e-mail: ebandreslgadea@unizar.es. 
The Working Paper Series seeks to disseminate original research in economics and finance. All papers have been anonymously refereed. By publishing these papers, the Banco de España aims to contribute to economic analysis and, in particular, to knowledge of the Spanish economy and its international environment.

The opinions and analyses in the Working Paper Series are the responsibility of the authors and, therefore, do not necessarily coincide with those of the Banco de España or the Eurosystem.

The Banco de España disseminates its main reports and most of its publications via the Internet at the following website: http://www.bde.es.

Reproduction for educational and non-commercial purposes is permitted provided that the source is acknowledged.

(c) BANCO DE ESPAÑA, Madrid, 2017

ISSN: 1579-8666 (on line) 


\section{Abstract}

The aim of this paper is to show the usefulness of Finite Mixture Markov Models (FMMMs) for regional analysis. FMMMs combine clustering techniques and Markov Switching models, providing a powerful methodological framework to jointly obtain business cycle datings and clusters of regions that share similar business cycle characteristics. An illustration with European regional data shows the sound performance of the proposed method.

Keywords: business cycles, clusters, regions, finite mixture Markov models.

JEL classification: C22, C32, E32, R11. 


\section{Resumen}

El objetivo de este trabajo es mostrar la utilidad de los modelos de Markov con mixturas finitas de distribuciones para el análisis regional. Estos modelos combinan técnicas de agrupamiento y modelos de Markov Switching, proporcionando un marco metodológico sólido que permite obtener de forma conjunta datados de los ciclos económicos regionales e identificar grupos de regiones que comparten características similares del ciclo económico. Se ilustra el buen funcionamiento del método propuesto con datos del PIB de las regiones europeas.

Palabras clave: ciclo económico, clusters, regiones, modelos de Markov con mixturas finitas de distribuciones.

Códigos JEL: C22, C32, E32, R11. 


\section{Introduction}

Studying the regional dimension of business cycles is important to uncover the heterogeneity hidden in country analyses. ${ }^{1}$ By dealing with a larger information set, new insights can be obtained, useful, for instance, when implementing economic policies. Nevertheless, the literature analyzing regional business cycles is relatively scant. This could be due to data limitations and technical difficulties to properly capture business cycles in small economic units.

The goal of this letter is to show the usefulness of Finite Mixture Markov models (FMMM), developed by Frühwirth-Schnatter and Kaufmann (2008), to identify common cyclical patterns among regions, that is, to show that the combination of clustering techniques and Markov Switching models provides a powerful methodological framework to analyze business cycles at a regional level and overcome the above-mentioned limitations. By using these techniques, it is possible to both obtain a business cycle dating and to identify clusters according to business cycle features. We present an empirical application for European regions.

\section{Finite Mixture Markov Models for regional analysis}

Business cycle analysis is usually carried out at national level and using quarterly or monthly data. The most common methods to obtain business cycle datings are the Bry and Boschan (1971) algorithm and Markov Switching models put forward by Hamilton (1989). From these individual datings, it is usual to analyze business cycle features, to detect patterns of synchronization or to build clusters of countries. $^{2}$ Analyzing the regional dimension introduces new challenges, especially for

\footnotetext{
${ }^{1}$ See, e.g., Ramajo et al. (2008) for the European regions and Park and Hewings (2012) for the US states.

${ }^{2}$ Some examples are Gadea et al. (2017b), Harding and Pagan (2006) and Camacho et al. (2006).
} 
dating business cycles of individual series. Note that the individual estimation of business cycles by regions usually exhibits large estimation errors because of short samples and high variability. ${ }^{3}$ Paraphrasing Stock and Watson (2010), the "aggregate (at national level) and then date" approach is usually preferred, in spite of the subsequent loss of valuable information, to the "date and then aggregate" approach. ${ }^{4}$

Against this background, the model-based clustering approach for multiple time series developed by Frühwirth-Schnatter and Kaufmann (2008) is suitable to analyze regional business cycles. ${ }^{5}$ This method can be used for finite mixtures of Markov Switching autoregressive models, in line with the seminal work of Hamilton (1989). The estimation technique, within a Bayesian framework, is Markov chain Monte Carlo (MCMC), which allows us to jointly estimate all the parameters of the model, including the groups of regions. The idea is to group time series and to pool within clusters to obtain posterior inferences, without an overall pooling being necessary, thus avoiding the heterogeneity bias. This means that, within a panel of time series, only those that display similar dynamic properties and share similar business cycle features are pooled to estimate the parameters, the appropriate grouping being estimated along with the model parameters.

Thus, by using this method a clear gain of efficiency is achieved. Other valuable features of this method are its flexibility, as it admits different specifications, such as autoregressive panels, and the abundant information provided, as the estimation of all the model parameters also includes uncertainty measures. In the next subsection, we describe the details and steps of the estimation process.

\footnotetext{
${ }^{3}$ Original data typically have an annual frequency. Even if available, quarterly series are short, not homogeneous across countries and, generally, artificially constructed by interpolating annual data.

${ }^{4}$ Nevertheless, there are some exceptions: Gadea et al. (2012) date and build clusters for the Spanish regions and Stock and Watson (2008) identify clusters from the idiosyncratic terms of a dynamic factor model for the US states' housing prices.

${ }^{5}$ Kaufmann (2010) applies this method to analyze the Austrian business cycle using a large set of series.
} 


\subsection{Finite Mixture Markov Models estimation process}

Let $y_{i t}$ be a set of time series from $t=1, \ldots, T$ for $i=1, \ldots, N, N$ being the number of regions which arise from $K$ groups, whereby for each group, $k=1, \ldots, K$, we define an econometric model to capture its business cycle with the same parameters, $\theta$. This model is based on the Markov-switching (MS) approach proposed by Hamilton (1989). In the simplest setting, MS models characterize a series through a process of a mean conditioned on a state of nature. The changes in value of this mean allow us to differentiate periods of expansions and recessions. In general, we consider the following process for the growth of the GDP, computed as the first difference of its log:

$$
y_{i t}=\mu_{i, B_{j}}+\epsilon_{i t}
$$

where $y_{i t}$ is the $\log$ difference of GDP of region $i$ in time $t, \mu_{i, B_{j}}$ is the vector of MS intercepts and $\epsilon_{i t} / B_{j} \sim \mathrm{N}\left(0, \sigma_{i}\right)$ if we consider that the variance of the errors is equal for all states. It is standard to assume that these varying parameters depend on an unobservable state variable $B_{j}$ that represents the business cycle state and evolves according to an irreducible $m$-state Markov process, where $p_{k j}$ controls the probability of a switch from state $j$ to state $k$.

In this framework, we use a classical MS model with 2 states $(j=1,2)$ that define two possible means, $\mu_{i, 1}$ and $\mu_{i, 2}$, which are associated with expansion and recession phases, respectively. A $2 \times 2$ transition matrix governs regime shifts, where $\xi_{i, 11}$ and $\xi_{i, 22}$ represent the probability of being in expansion or recession, respectively, and remaining in the same state in the following period; $\xi_{i, 12}$ denotes the probability of switching from recession to expansion and $\xi_{i, 21}$ is the probability of switching from expansion to recession. ${ }^{6}$

\footnotetext{
${ }^{6} \mathrm{~A}$ habitual extension is to introduce dynamics in this basic framework.
} 
As the MS model provides a dating procedure for each region, a methodology for clustering is needed. The first step is to introduce a latent group indicator $S_{i}$ that denotes to which group $y_{i}$ belongs for all $t$. This is,

$$
p\left(y_{i} \mid \theta_{S_{i}}\right)=\left\{\begin{array}{c}
p\left(y_{i} \mid \theta_{S_{1}}\right), S_{i}=1 \\
\ldots \\
p\left(y_{i} \mid \theta_{S_{K}}\right), S_{k}=K
\end{array}\right.
$$

Notice that the number of groups, the allocation of each region to a given group and the group-specific parameters $\theta=\left(\theta_{1}, \ldots, \theta_{K}\right)$ are estimated from the data. We also define a probabilistic model for $P\left(S_{i}=k\right)$.

Combining the MS model for business cycle dating and the finite mixture for clustering, the basic model is specified as follows:

$$
y_{i t}=\mu_{k}^{G}+\delta_{1, k}^{G} y_{i, t-1}+\ldots+\delta_{p, k}^{G} y_{i, t-p}+\left(I_{k t}-1\right)\left(\mu_{k}^{R}+\delta_{1, k}^{R} y_{i, t-1}+\ldots+\delta_{p, k}^{R} y_{i, t-p}\right)+\epsilon_{i t}
$$

where $y_{i t}$ represents the GDP growth rate of region $i$ in time $t$ and $p$ the order of the autoregressive dynamics. Therefore, $\mu_{k}^{G}$ and $\delta_{j, k}^{G}$ for $j=1, \ldots p$ are the group-specific effects and $\mu_{k}^{R}$ and $\delta_{j, k}^{R}$ the state-specific effects. The group indicator is defined as $S_{i}=k$ with $k=1 \ldots K$. Periods of expansion (above-average growth periods) are denoted by $I_{k t}=1$ with intercept $\mu_{k}^{G}$ and periods of recession (below-average growth periods) are denoted by $I_{k t}=0$ with intercept $\mu_{k}^{G}-\mu_{k}^{R}$. We consider that the autoregressive dynamic is different for each group, thus $\delta_{j, k}^{G}$ and $\delta_{j, k}^{G}-\delta_{j, k}^{R}, j=1, \ldots p$.

Denoting by $\varphi=(\theta, \eta, \xi)$, we estimate the set of state-specific and group-specific parameters $\theta$, the transition matrix $\xi_{k, j j}$, the group probabilities, $\eta=\left(\eta_{1}, \ldots, \eta_{K}\right)$ and, implicitly, the number of groups, $K$. Disturbance terms have unit-specific variances $\epsilon_{i t} \sim N\left(0, \sigma_{i}^{2}\right)$ with $\sigma_{i}^{2}=\sigma^{2} / \lambda_{i}$.

This is achieved within the Bayesian framework by applying Markov chain Monte Carlo and data augmentation methods and estimate the joint posterior $p(\varphi, S \mid y) \propto p(y \mid \varphi, S) p(S \mid \varphi) p(\varphi)$ in two steps. First, each time series is classified in 
one of the $K$ groups by sampling the groups indicator $S_{i}$ from the posterior distribution $P\left(S_{i}=k \mid y, \varphi\right)$, and secondly, conditional on known indicators $S=\left(S_{1}, \ldots, S_{K}\right)$ the estimation of the parameters is carried out by sampling then from the posterior probabilities $p(\varphi \mid S, y){ }^{7}$ For estimation purposes, 5,000 draws and non-informative priors are considered. ${ }^{8}$ We use independent priors with the hyperparameters recommended by Frühwirth-Schnatter and Kaufmann (2008): ${ }^{9}$

- $\eta_{1}, \ldots, \eta_{k} \sim D(1, \ldots 1)$

- $\sigma^{2} \sim G^{-1}(1,1)$

- $\lambda_{i} \sim G(4,4)$

- $\xi_{k, j j} \sim B(3,1), j=1,2$

- $\mu_{k}^{G} \sim N(0,4)$ and $\mu_{k}^{G}-\mu_{k}^{R} \sim N(0,4)$

- $\delta_{l, k}^{G} \sim N(0,1)$

- $\delta_{l, k}^{G}-\delta_{l, k}^{R} \sim N(0,1)$

- $l=1, \ldots, p$, for $k=1, \ldots, K$.

where D denotes a Dirichlet distribution; G, a Gamma distribution; and B, a Beta distribution.

The number of components, $K$, can be selected through the point-process representation or maximum likelihood. We apply three different criteria to estimate the likelihood function: importance sampling, bridge sampling and reciprocal sampling.

\footnotetext{
${ }^{7}$ We follow the approach of Frühwirth-Schnatter and Kaufmann (2008).

${ }^{8}$ All the calculations have been done using the Matlab Toolbox provided by Frühwirth-Schnatter (2008) and the specific codes that Silvia Kaufmann kindly shared.

${ }^{9}$ For a more detailed discussion about priors selection in finite mixtures and Markov Switching models, see Frühwirth-Schnatter (2006).
} 
The last issue before classifying the groups is their identification to avoid labelswitching problems. In this regard, we use the combination of two restrictions. The first one identifies states by $\mu_{k}^{R}>0, \forall k=1, \ldots, K$ to ensure that $\mu_{k}^{G}>\mu_{k}^{G}-$ $\mu_{k}^{R}$, that is, the mean in expansions is above the mean in recessions. The second identifies states within each group. In this case, different groups of parameters can be used. This empirical strategy consists of trying the following three alternatives of identification: either $\delta_{j, 1}^{G}<\delta_{j, 2}^{G}<\ldots<\delta_{j, K}^{G} \forall j=1, \ldots, p, \mu_{1}^{R}<\mu_{2}^{R}>\ldots<\mu_{K}^{R}$ or $\mu_{1}^{G}>\mu_{1}^{G}>\ldots>\mu_{K}^{G}$. Then, we select the most suitable clustering from a visual inspection of scatterplots and through the ability of the identified model to separate groups unequivocally. The aim is to get the largest possible number of units within one group or another. The units are placed in a group according to their probability, computed using expression 2, which has to be above 0.5 .

\section{Illustration: European regions}

We consider GDP data corresponding to 213 NUTS-2 regions from 16 European countries: Austria, Belgium, Finland, France, Germany, ${ }^{10}$ Ireland, Italy, Luxembourg, the Netherlands, Portugal, Spain, Greece, Denmark, Sweden, the UK and Norway. The series cover a period of 32 years, from 1980 to 2011. The source of the data is Cambridge Econometrics.

We estimate different specifications depending on the number of groups $K=$ $1,2,3,4,5,6$ and lags $p=1,2$. The three sampling likelihood criteria are considered to select the best model. All of them agree that the preferred model for European regions includes two lags of GDP and identifies five groups, i.e. $p=2$ and $K=$ 5 , respectively (see Table 1 ). The second-best performing models, which are also analyzed to illustrate the performance of the method, consider 4 and 6 groups and 2 lags.

\footnotetext{
${ }^{10}$ The eastern Landers and Berlin are not included in the analysis because there is no data prior to 1991.
} 
Scatterplots of the MCMC processes for different pairs of parameters are displayed in Figure 1, which shows the posterior draws following a Bayesian estimation for the preferred model $K=5$ and the other two possible candidates. Each point of the scatterplot offers the location of the draws of the posterior estimated parameters. Different colors represent each cluster of European regions. Clustering is clearer in the model with five groups, whatever the parameters considered, supporting the model selected by the likelihood criteria.

Regarding the identification of groups, we have imposed some restrictions in addition to $\mu_{K}^{R}>0, \forall K$, which are detailed in the first column of Table 2. The percentage of regions that are not unambiguously allocated to a group, with a probability greater than 0.5 , following these identification restrictions, is presented in the second column of the table for $K=5$. Notice that considering $\mu_{1}^{G}>\mu_{1}^{G}>\ldots>\mu_{K}^{G}$ or, equivalently, ordering the clusters from the highest to the lowest growth during an expansion period, we get a classification of almost $100 \%$ of the regions. ${ }^{11}$

The probability by region of belonging to each of the five groups is depicted in Figure 2. We assign each region to the group for which its probability of belonging is above 0.5 . The probability of being in each group is, in most cases, close to one. The probability of belonging to group five, the one that concentrates most of the regions, is also quite high in many of the regions that are classified in other groups.

Figure 3 depicts some of the main features of the five clusters. The first plot is related to the cyclical phase. We observe that the probability of recession clearly differs among the clusters, the highest probability corresponding to cluster one and the lowest in cluster five. The second and the third plots represent economic conditions. The lowest weight of the industrial sector is in cluster one and is clearly below the average of all the European regions. Cluster one also displays the highest unemployment rate while the rest of the clusters are all below the European average. In order to get a geographical classification of the regions, in the last plot we

\footnotetext{
${ }^{11}$ Figures for the other parameters are available upon request.
} 
define groups of countries ${ }^{12}$ and compute the percentage of regions in each cluster belonging to each group. It seems that clusters one, two and three are related to geographical criteria, while clusters four and five include regions of different groups of countries (See Bandres, et al., 2017).

In order to document the business cycle estimates of each of the five clusters and the European business cycle as a whole, we present Figure 4. We observe that cluster five is representative of the European business cycle. The timing of the business cycle is different in the rest of the clusters, especially cluster one, since they undergo more recessionary periods.

On the whole, we can confirm the ability of the FMMM to properly capture the variability of the regional cycles.

\section{Concluding remarks}

This letter illustrates the usefulness of FMMM for estimating and clustering regional business cycles. This method allows us to jointly estimate the parameters associated with the business cycles and to cluster regions with similar characteristics, overcoming the weaknesses of other techniques when applied to regional data. An empirical application to a set of European regions shows the suitable performance of this methodological framework. A more detailed analysis of the estimated parameters and the features characterizing each cluster would give us valuable information of the European business cycle.

\footnotetext{
${ }^{12}$ Specifically, "Central countries" (Belgium, Germany, France, The Netherlands, Luxembourg and Austria), "Nordic countries" (Denmark, Sweden, Norway and Finland), "Mediterranean countries" (Greece, Italy, Portugal and Spain) and "British Isles" (Ireland and the UK). Gadea, et al. (2017a) define a similar grouping of countries.
} 


\section{References}

[1] Bandrés, E., Gadea, M. D. and Gómez-Loscos, A. (2017). Regional Business Cycles Across Europe, Occasional Paper, Banco de España, 1702.

[2] Bry, G. and Boschan, C. (1971). Cyclical analysis of time series: selected procedures and computer programs, NBER, New York.

[3] Camacho, M., Perez-Quiros, G. and Saiz, L. (2006). Are business cycles close enough to be just one?. Journal of Economic Dynamics and Control, 30, 16871706 .

[4] Frühwirth-Schnatter, S. (2006). Finite Mixture and Markov Switching Models, New York: Springer-Verlag, 1st edn.

[5] Frühwirth-Schnatter, S. and Kaufmann, S. (2008). Model-based clustering of multiple time series, Journal of Business and Economic Statistics, 26, 78-89.

[6] Gadea, M. D., Gómez-Loscos, A. and Montañés, A. (2012). Cycles inside cycles: Spanish regional aggregation, SERIEs Journal of the Spanish Economic Association, 3(4), 423-456.

[7] Gadea, M. D., Gómez-Loscos, A. and Leiva-Leon, D. (2017a). The evolution of regional economic interlinkages in Europe, Working Paper, Banco de España 1705

[8] Gadea, M. D., Gómez-Loscos, A., and Perez-Quiros, G. (2017b). Dissecting US recoveries, Economics Letters, 154, 59-63.

[9] Hamilton, J.D. (1989). A new approach to the economic analysis of nonstationary time series and the business cycle, Econometrica, 57(2), 357-84.

[10] Harding, D. and Pagan, A. (2006). Synchronization of cycles, Journal of Econometrics, 132(1), 59-79. 
[11] Kaufmann, S. (2010). Dating and forecasting turning points by Bayesian clustering with dynamic structure. A suggestion with an application to Austrian data, Journal of Applied Econometrics, 25, 309-344.

[12] Yangsu, P. and Hewings, G. J. (2012). Does industry mix matter in regional business cycles?, Studies in Regional Science, 42(1), 39-60.

[13] Ramajo, J., Marquez, M.A., Hewings, G. and Salinas, M.M. (2008). Spatial heterogeneity and interregional spillovers in the European Union: Do cohesion policies encourage convergence across regions?, European Economic Review, 52, $551-567$.

[14] Stock, J.H. and Watson, M. (2008). The Evolution of National and Regional Factors in U.S. Housing Construction. Volatility and Time Series Econometrics: Essays in Honor of Robert F. Engle, eds. Bollerslev, T., Russell, J. and Watson, M. Oxford: Oxford University Press.

[15] Stock, J.H. and Watson, M. (2010). Indicators for Dating Business Cycles: Cross-History Selection and Comparisons, American Economic Review: Papers 63 Proceedings, 16-19. 


\section{Tables}

Table 1: Log-marginal likelihood of different Markov Switching model specifications with group-specific autoregressive coeffients

\begin{tabular}{l|ccc}
\hline \hline Model K,p & Importance sampling & Bridge Sampling & Reciprocal Sampling \\
\hline 1,1 & -14561.98 & -14561.28 & -14561.98 \\
1,2 & -13986.91 & -13986.20 & -13986.90 \\
2,1 & -13986.91 & -13986.20 & -13986.90 \\
2,2 & -13948.44 & -13948.00 & -13948.71 \\
3,1 & -14430.85 & -14429.66 & -14430.89 \\
3,2 & -13795.62 & -13794.28 & -13795.33 \\
4,1 & -13948.44 & -13948.00 & -13948.71 \\
4,2 & -13778.06 & -13774.50 & -13775.67 \\
5,1 & -14361.92 & -14419.50 & -14419.22 \\
5,2 & $\mathbf{- 1 3 7 3 7 . 0 3}$ & $\mathbf{- 1 3 7 2 4 . 2 6}$ & $\mathbf{- 1 3 7 3 0 . 1 8}$ \\
6,1 & -13795.62 & -13794.28 & -13795.33 \\
6,2 & $\mathbf{- 1 3 7 4 8 . 1 3}$ & $\mathbf{- 1 3 7 4 3 . 9 7}$ & $\mathbf{- 1 3 7 4 8 . 2 5}$ \\
\hline
\end{tabular}

Notes: The highest values are indicated in bold.

Table 2: Identification strategy

\begin{tabular}{l|c}
\hline \hline$\mu_{K}^{R}>0, \forall K$ & \% of non-assigned regions \\
\hline$\delta_{j, 1}^{G}<\delta_{j, 2}^{G}<\ldots<\delta_{j, K}^{G} \forall j=1, \ldots, p$ & 0.01 \\
$\mu_{1}^{R}<\mu_{2}^{R}>\ldots<\mu_{K}^{R}$ & 0.24 \\
$\mu_{1}^{G}>\mu_{1}^{G}>\ldots>\mu_{K}^{G}$ & 0.00 \\
\hline \hline
\end{tabular}

Notes: The first column indicates the identification restrictions used in combination with the restriction $\mu_{K}^{R}>0, \forall K$. The second column indicates the percentage of regions that are not unambiguously allocated to a group. 


\section{$6 \quad$ Figures}
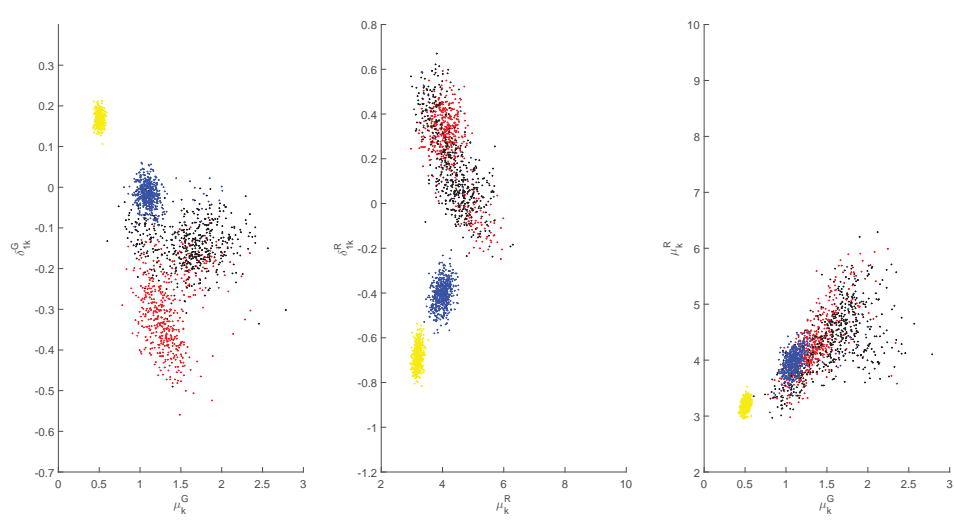

(a) $\mathrm{K}=4, \mathrm{p}=2$
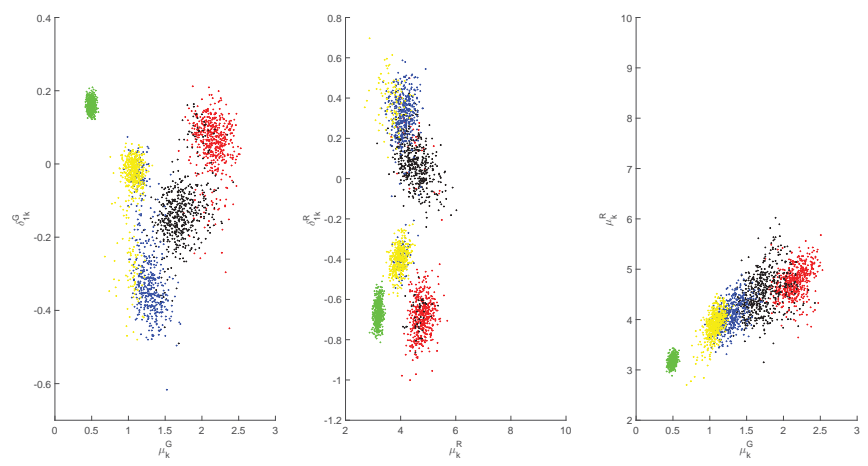

(b) $\mathrm{K}=5, \mathrm{p}=2$
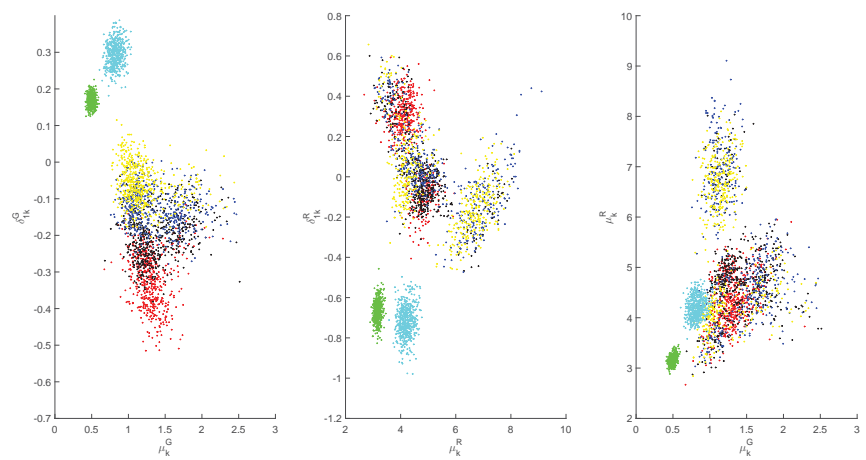

(c) $\mathrm{K}=6, \mathrm{p}=2$

Figure 1: Scatterplots of the MCMC draws

Notes: From left to right, scatterplot MCMC draws of simulated group-specific parameters $\mu_{k}^{G}$ against $\delta_{1, k}^{G}$, scatterplot of simulated state-group specific effects $\mu_{k}^{R}$ against $\delta_{1, k}^{R}$ and scatterplot of simulated group-specific parameters $\mu_{k}^{G}$ against $\mu_{k}^{R}$. The scatterplots display values for $\mathrm{k}=1, \ldots, \mathrm{K}$. 


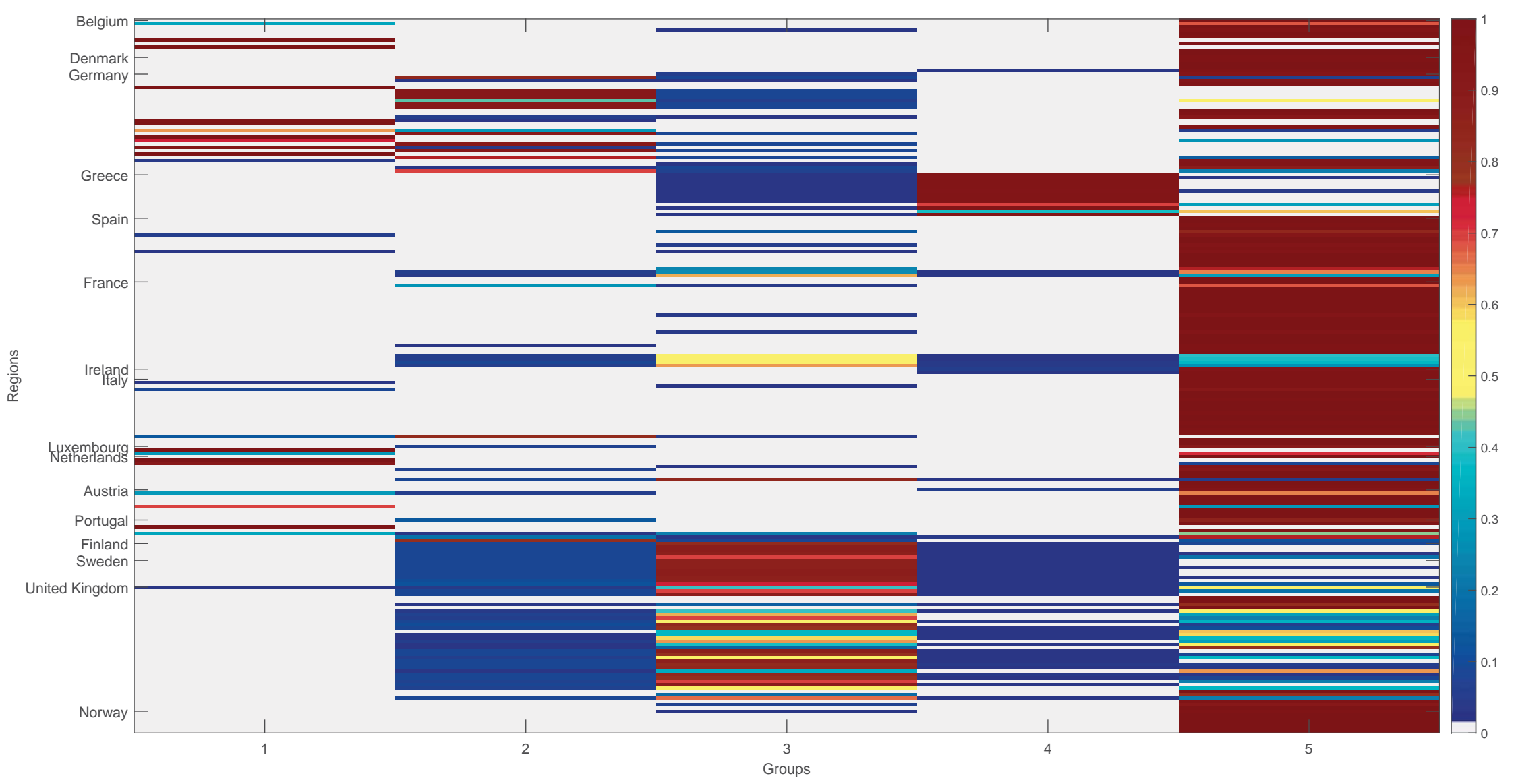

Figure 2: Probability by region of being in each group

Notes: This figure shows the probability of each region belonging to each group. The lowest probability of being in a group is illustrated with the lightest colors, while the highest probability is represented in brown. The regions belonging to each country are on the y-axis. 

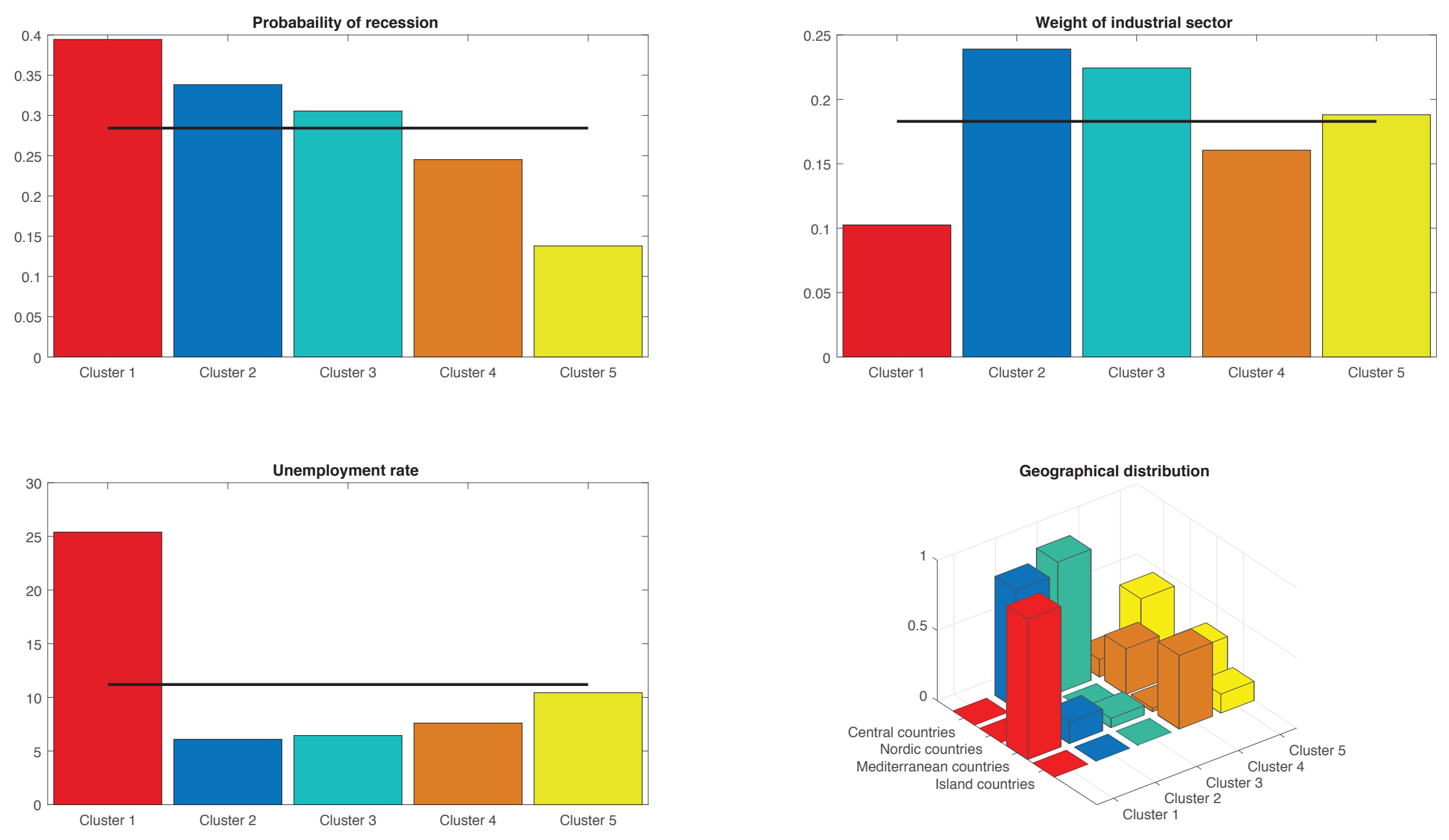

Figure 3: Some features by cluster 

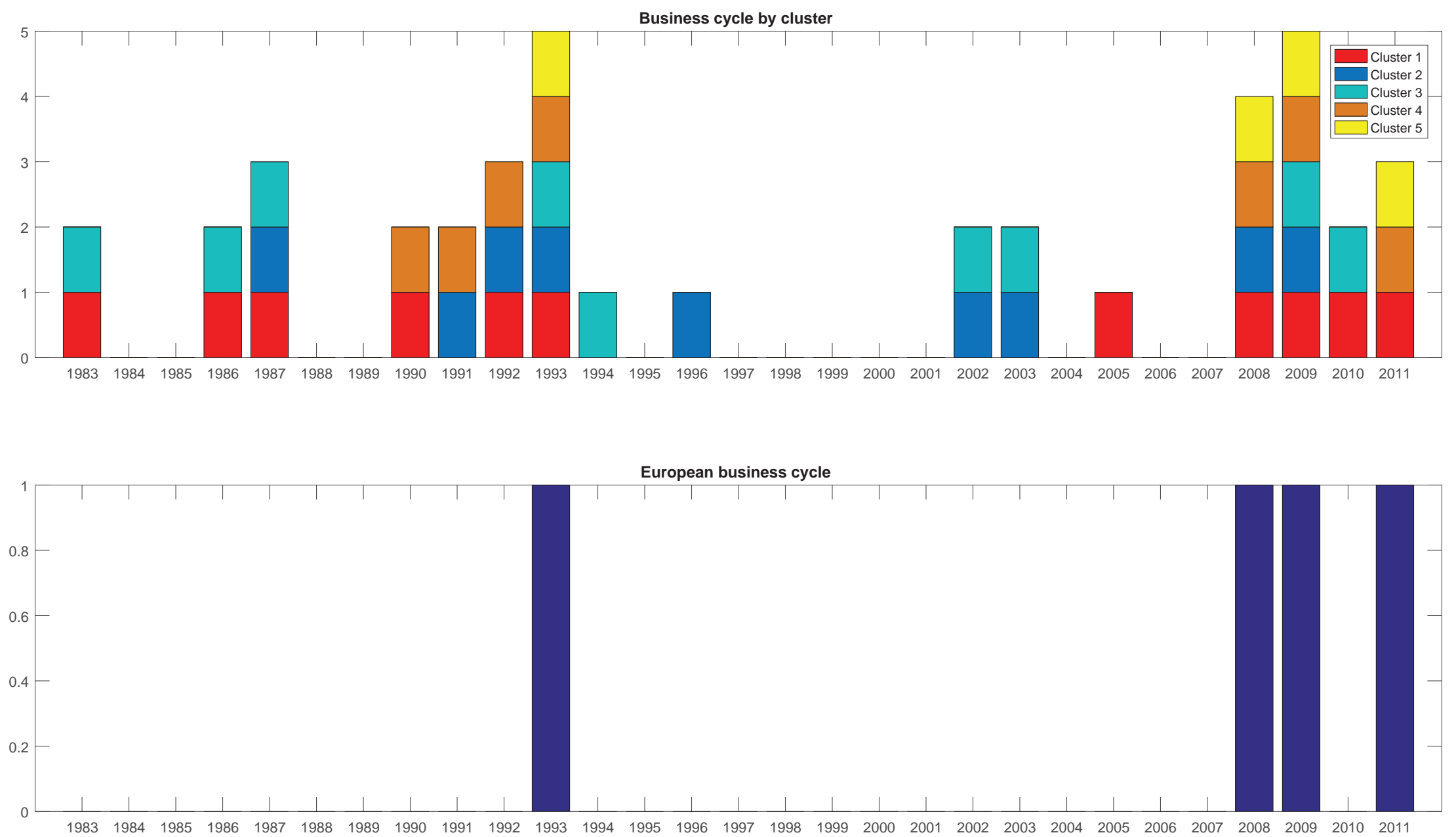

Figure 4: Business cycle estimates 


\title{
BANCO DE ESPAÑA PUBLICATIONS
}

\author{
WORKING PAPERS
}

1621 ADRIAN VAN RIXTEL, LUNA ROMO GONZÁLEZ and JING YANG: The determinants of long-term debt issuance by European banks: evidence of two crises.

1622 JAVIER ANDRÉS, ÓSCAR ARCE and CARLOS THOMAS: When fiscal consolidation meets private deleveraging.

1623 CARLOS SANZ: The effect of electoral systems on voter turnout: evidence from a natural experiment.

1624 GALO NUÑO and CARLOS THOMAS: Optimal monetary policy with heterogeneous agents.

1625 MARÍA DOLORES GADEA, ANA GÓMEZ-LOSCOS and ANTONIO MONTAÑÉS: Oil price and economic growth: a long story?

1626 PAUL DE GRAUWE and EDDIE GERBA: Stock market cycles and supply side dynamics: two worlds, one vision?

1627 RICARDO GIMENO and EVA ORTEGA: The evolution of inflation expectations in euro area markets.

1628 SUSANA PÁRRAGA RODRÍGUEZ: The dynamic effect of public expenditure shocks in the United States.

1629 SUSANA PÁRRAGA RODRÍGUEZ: The aggregate effects of government incometransfer shocks - EU evidence.

1630 JUAN S. MORA-SANGUINETTI, MARTA MARTÍNEZ-MATUTE and MIGUEL GARCÍA-POSADA: Credit, crisis and contract enforcement: evidence from the Spanish loan market.

1631 PABLO BURRIEL and ALESSANDRO GALESI: Uncovering the heterogeneous effects of ECB unconventional monetary policies across euro area countries.

1632 MAR DELGADO TÉLLEZ, VÍCTOR D. LLEDÓ and JAVIER J. PÉREZ: On the determinants of fiscal non-compliance: an empirical analysis of Spain's regions.

1633 OMAR RACHEDI: Portfolio rebalancing and asset pricing with heterogeneous inattention.

1634 JUAN DE LUCIO, RAÚL MÍNGUEZ, ASIER MINONDO and FRANCISCO REQUENA: The variation of export prices across and within firms.

1635 JUAN FRANCISCO JIMENO, AITOR LACUESTA, MARTA MARTÍNEZ-MATUTE and ERNESTO VILLANUEVA: Education, labour market experience and cognitive skills: evidence from PIAAC.

1701 JAVIER ANDRÉS, JAVIER J. PÉREZ and JUAN A. ROJAS: Implicit public debt thresholds: an empirical exercise for the case of Spain.

1702 LUIS J. ÁLVAREZ: Business cycle estimation with high-pass and band-pass local polynomial regression.

1703 ENRIQUE MORAL-BENITO, PAUL ALLISON and RICHARD WILLIAMS: Dynamic panel data modelling using maximum likelihood: an alternative to Arellano-Bond.

1704 MIKEL BEDAYO: Creating associations as a substitute for direct bank credit. Evidence from Belgium.

1705 MARÍA DOLORES GADEA-RIVAS, ANA GÓMEZ-LOSCOS and DANILO LEIVA-LEON: The evolution of regional economic interlinkages in Europe.

1706 ESTEBAN GARCÍA-MIRALLES: The crucial role of social welfare criteria for optimal inheritance taxation.

1707 MÓNICA CORREA-LÓPEZ and RAFAEL DOMÉNECH: Service regulations, input prices and export volumes: evidence from a panel of manufacturing firms.

1708 MARÍA DOLORES GADEA, ANA GÓMEZ-LOSCOS and GABRIEL PÉREZ-QUIRÓS: Dissecting US recoveries.

1709 CARLOS SANZ: Direct democracy and government size: evidence from Spain.

1710 HENRIQUE S. BASSO and JAMES COSTAIN: Fiscal delegation in a monetary union: instrument assignment and stabilization properties.

1711 IVÁN KATARYNIUK and JAIME MARTÍNEZ-MARTÍN: TFP growth and commodity prices in emerging economies.

1712 SEBASTIAN GECHERT, CHRISTOPH PAETZ and PALOMA VILLANUEVA: Top-down vs. bottom-up? Reconciling the effects of tax and transfer shocks on output.

1713 KNUT ARE AASTVEIT, FRANCESCO FURLANETTO and FRANCESCA LORIA: Has the Fed responded to house and stock prices? A time-varying analysis.

1714 FÁTIMA HERRANZ GONZÁLEZ and CARMEN MARTÍNEZ-CARRASCAL: The impact of firms' financial position on fixed investment and employment. An analysis for Spain.

1715 SERGIO MAYORDOMO, ANTONIO MORENO, STEVEN ONGENA and MARÍA RODRÍGUEZ-MORENO: "Keeping it personal" or "getting real"? On the drivers and effectiveness of personal versus real loan guarantees. 
1716 FRANCESCO FURLANETTO and ØRJAN ROBSTAD: Immigration and the macroeconomy: some new empirical evidence.

1717 ALBERTO FUERTES: Exchange rate regime and external adjustment: an empirical investigation for the U.S.

1718 CRISTINA GUILLAMÓN, ENRIQUE MORAL-BENITO and SERGIO PUENTE: High growth firms in employment and productivity: dynamic interactions and the role of financial constraints.

1719 PAULO SOARES ESTEVES and ELVIRA PRADES: On domestic demand and export performance in the euro area countries: does export concentration matter?

1720 LUIS J. ÁLVAREZ and ANA GÓMEZ-LOSCOS: A menu on output gap estimation methods.

1721 PAULA GIL, FRANCISCO MARTÍ, JAVIER J. PÉREZ, ROBERTO RAMOS and RICHARD MORRIS: The output effects of tax changes: narrative evidence from Spain.

1722 RICARDO GIMENO and ALFREDO IBÁÑEZ: The eurozone (expected) inflation: an option's eyes view.

1723 MIGUEL ANTÓN, SERGIO MAYORDOMO and MARÍA RODRÍGUEZ-MORENO: Dealing with dealers: sovereign CDS comovements.

1724 JOSÉ MANUEL MONTERO: Pricing decisions under financial frictions: evidence from the WDN survey.

1725 MARIO ALLOZA: The impact of taxes on income mobility.

1726 DANILO LEIVA-LEON: Measuring business cycles intra-synchronization in US: a regime-switching interdependence framework.

1727 PIERRE GUÉRIN and DANILO LEIVA-LEON: Model averaging in Markov-Switching models: predicting national recessions with regional data.

1728 MÁXIMO CAMACHO and DANILO LEIVA-LEON: The propagation of industrial business cycles.

1729 JAMES COSTAIN: Costly decisions and sequential bargaining.

1730 MARIO ALLOZA: Is fiscal policy more effective in uncertain times or during recessions?

1731 PIERRE GUÉRIN and DANILO LEIVA-LEON: Monetary policy, stock market and sectoral comovement.

1732 HENRIK JENSEN, IVAN PETRELLA, SØREN HOVE RAVN and EMILIANO SANTORO: Leverage and deepening business cycle skewness.

1733 CÉSAR MARTÍN MACHUCA: External stress early warning indicators.

1734 RODOLFO G. CAMPOS: International migration pressures in the long run.

1735 ANDREA ARIU, ELENA BIEWEN, SVEN BLANK, GUILLAUME GAULIER, MARÍA JESÚS GONZÁLEZ, PHILIPP MEINEN, DANIEL MIRZA, CÉSAR MARTÍN MACHUCA and PATRY TELLO: Firm heterogeneity and aggregate business services exports: micro evidence from Belgium, France, Germany and Spain.

1736 LEONARDO GAMBACORTA, STEFANO SCHIAFFI and ADRIAN VAN RIXTEL: Changing business models in international bank funding.

1737 ENRIQUE MORAL-BENITO and FRANCESCA VIANI: An anatomy of the Spanish current account adjustment: the role of permanent and transitory factors.

1738 MARÍA J. NIETO and LARRY D. WALL: Cross-border banking on the two sides of the Atlantic: does it have an impact on bank crisis management?

1739 JACOPO TIMINI: Currency unions and heterogeneous trade effects: the case of the Latin Monetary Union.

1740 PAULINO FONT, MARIO IZQUIERDO and SERGIO PUENTE: Subsidising mature age employment or throwing coins into a wishing well: a quasi-experimental analysis.

1741 THOMAS FUJIWARA and CARLOS SANZ: Norms in bargaining: evidence from government formation in Spain.

1742 ENRIQUE ALBEROLA, ÁNGEL ESTRADA and FRANCESCA VIANI: Global imbalances from a stock perspective.

1743 ÓSCAR ARCE, RICARDO GIMENO and SERGIO MAYORDOMO: Making room for the needy: the credit-reallocation effects of the ECB's corporate QE.

1744 M. D. GADEA-RIVAS, ANA GÓMEZ-LOSCOS and EDUARDO BANDRÉS: Clustering regional business cycles.

\section{BANCODEESPAÑA}

Eurosistema
Unidad de Servicios Auxiliares

Alcalá, 48 - 28014 Madrid

E-mail: publicaciones@bde.es www.bde.es 